\title{
Aspectos da Autonomia Municipal no Direito Parlamentar Brasileiro
}

\author{
José de Queirós Campos \\ Assessor do Senado Federal; \\ Jornalista Profissional
}

\begin{abstract}
SUMÁRIO: 1. O Prefeito nomeado e a Câmara eleita. 2. Raizes da autonomia municipal. 3. Competência ampla na Constituição de 1824 , restrições do Ato Adicional de 1834 e restauração republicana. 4 . Eleição dos representantes e competência tributária. 5. Aspectos da evolução histórica. 6. Matéria e objeto do Decreto-lei n. ${ }^{\circ} 411 / 69$. 7. Questões suscitadas em torno da sua aplicação. 8. O problema da remuneração dos Vereadores nos Territórios. 9. Uma interpretação contestatória. 10. Decisão do Supremo quanto ao preenchimento das vagas dos Vereadores. 11. A solução em algumas Constituições estaduais. 12. Porque Vereador não é Parlamentar. 13. Inaplicabilidade imediata do art. 36 da Constituição aos Vereadores. 14. O problema da remuneração à vereança nas Capitais dos Territórios. 15. Como estabelecer o quantitativo dessa remuneração. 16. CONCLUSÕES.
\end{abstract}

1. Quando o Decreto-lei $n .{ }^{\circ} 411$, de 8 de janeiro de 1969 , conferiu autonomia aos Municípios dos Territórios Federais, enquanto os respectivos Prefeitos continuavam nomeados e demissíveis "ad nutum" pelos Governadores, começaram a surgir, naquelas unidades - Rondônia, Roraima e Amapá - alguns problemas de ordem administrativa a suscitar a atenção dos estudiosos do Direito Parlamentar, matéria que não se preleciona nos cursos jurídicos do País e de escassa bibliografia nacional.

Tais problemas, levados, largamente, à consideração da Consultoria Jurídica do Ministério do Interior e da Assessoria Jurídica do SERFHAU, motivaram algumas dezenas de pareceres, principalmente depois da outorga da Emenda Constitucio- 
nal $n .^{\circ} 1$, de 17 de outubro de 1969. É que alguns hermeneutas, combinando a interpretação dos artigos 36 e 200 da Carta assim alterada, enquanto confundiam a figura do Vereador com a do Parlamentar, concluíam no sentido de que só se daria a convocação do suplente à vereança em caso de morte, renúncia ou investidura do titular na função de Secretário do Município.

Entretanto, uma análise menos superficial do problema leva à conclusão de que aquela Emenda Constitucional não revogou os dispositivos do Decreto-lei $n .{ }^{\circ} 411 / 69$ que configuram a Lei Orgânica dos Municípios dos Territórios Federais.

2. A autonomia municipal é um instituto de profundas raízes no nosso Direito Administrativo, remontando às Ordenações portuguesas, anteriores ao Descobrimento do Brasil. Assim, em 1530 e em 1532, Martim Afonso, ao fundar casa forte e oficina na praia de São Cristóvão, no Rio de Janeiro, e ao criar a Vila de São Vicente, em São Paulo, obedeceu "em tudo ao regime comum às vilas da Coroa e às do Mestrado de Cristo". No último caso, tanto construiu a Casa da Câmara, como convocou "homens bons" para proceder à eleição dos Vereadores".

Vale ressaltar que, enquanto os Capitães-Mores de El-Rei tinham a incumbência de criar vilas, suas Câmaras só se podiam eleger mediante provisão régia. ${ }^{1}$ Por isso havia, no século XVI, dezoito Câmaras Municipais no Brasil, todas compostas eletivamente, acumulando funções legislativas, judiciais e executivas. ${ }^{2}$

É bem verdade que no Império, com o surgimento das Províncias, houve tendência à absorção, por elas, da autonomia municipal, assegurada, no entanto, por todas as Constituições republicanas, salvo o interregno de 1937 a 1947, quando inexistentes as Câmaras Municipais.

3. A Constituição de 25 de março de 1824 reservou um capítulo ao problema, determinando a existência de Câmaras "em todas as cidades e vilas", encarregadas do "governo econômico municipal" (art. 167), eleitos seus membros (art. 168), com ampla competência, para a "formação das suas posturas policiais, aplicação das suas rendas e todas as suas particulares e úteis atribuições" (art. 68). 
Mas o Ato Adicional de 12 de agosto de 1834 reduziu essa autonomia, tornando competentes as Assembléias Legislativas Provinciais para dispor (art. 10) sobre a desapropriação por utilidade municipal $\left(\S 3 .^{\circ}\right)$, a polícia e economia municipal, examinando propostas das Câmaras respectivas, a "criação, supressão e nomeação para os empregos municipais e o estabelecimento dos respectivos ordenados $\left(\S 7 .^{\circ}\right)$.

Comentando a nova disciplina administrativa, dizia Carneiro Maia: ${ }^{3}$

"O Ato Adicional foi para as Câmaras Municipais do Brasil um legado funesto da Revolução", pois "empiorou a sorte das municipalidades, como foi uma contradição palpável com os mesmos princípios, de liberdade administrativa, que haviam incitado a reforma de 1834".

Entretanto, a Constituição de 1891, em seu art. 68, voltou a assegurar "a autonomia dos Municípios em tudo quanto respeite ao seu peculiar interesse", enquanto 0 art. 13 da Constituição de 1934, garantindo a eletividade do Prefeito e dos Vereadores, permitia, no $\S 1 .^{\circ}$, a nomeação daquele pelo Governo do Estado "no Município da Capital e nas estâncias hidrominerais", restrição conservada na Carta de 1946, com um acréscimo:

"Serão nomeados pelos Governadores dos Estados os Prefeitos dos Municípios que a lei federal, mediante parecer do Conselho de Segurança Nacional, declarar bases ou portos militares de excepcional importância para a defesa externa do País" $\left(\S 2 .^{\circ}\right.$ do art. 28).

A Constituição de 1967, mantida, no particular, pela Emenda Constitucional n. $1 / 69$, confere aos Governadores, com prévia aprovação das Assembléias Legislativas, a nomeação dos Prefeitos das Capitais e dos Municípios considerados estâncias hidrominerais, e, ao Presidente da República, nomear os dos Municípios declarados de interesse da Segurança Nacional por lei de iniciativa do Poder Executivo (art. 17, §§ $1 .^{\circ}$ e $3^{\circ}$ ).

Embora Pontes de Miranda assinale que "o municipalismo Serviu, porém não é essencial à democracia," ${ }^{4}$ Rosah Russomano comenta: ${ }^{5}$ 
“Não obstante, dentro do sistema federativo, pode desenvolver-se o Município, que simboliza, em verdade, o núcleo onde nasceu e do qual se projetam as mais expressivas idéias democráticas. Tal era, em última análise, o pensamento de Kelsen, que valorizou a autonomia municipal, assim como fez Pio XI, na "Quadragesimo Anno", ao acentuar que essa autonomia apresenta conexões diretas, também, com o espiritual, sendo erro grave, que vai ao arrepio da ordem moral, o relegar-se a uma comunidade extensa e supeperior tudo aquilo que coletividades menores e menos elevadas podem cumprir e obter".

4. Releva salientar que a autonomia municipal contempla, especificamente, a competência tributária, o que conduz Ferreira
Filho ao seguinte comentário: ${ }^{6}$

“A Constituição Federal prevê o Município como entidade preexistente e mesmo como necessária, na medida que the confere competência e discrimina rendas. A competência que lhe é concedida pela Constituição o é, aliás, nos mesmos termos que a da União. Esta e o Município têm os poderes enumerados, os Estados-membros os poderes remanescentes".

De qualquer modo, se há restrições, no sistema constitucional brasileiro, à eleição dos Prefeitos, elas inexistem quanto à dos Vereadores. Assim, a autonomia político-administrativa dos Municípios repousa, principalmente, na eleição direta
da Câmara respectiva.

Aliás João José de Queiroz ${ }^{7}$ considera esta, desde a Colônia, a característica primordial da edilidade brasileira, ao assi-
nalar:

"Foram as Câmaras Municipais as primeiras assembléias eletivas que o Brasil conheceu. Posto que - como assinala Oliveira Viana - não se possa considerar democrático, no sentido moderno da expressão, o governo das nossas edilidades no período colonial, o certo é que os antigos Conselhos representavam, em face da Coroa e muitas vezes a ela se opondo, apreciável força política. Exemplo do papel que Ihes cabia no Estado Colonial era a prerrogativa de se fazerem representar junto às Cortes, aliás não 
convocadas por dois séculos. A elas entretanto enviaram seus deputados: a Câmara do Rio de Janeiro, em 1641 , e de São Paulo, em 1685".

5. Com vários nomes - Câmara, Conselho, Mesa de Vereação e até Senado, como a da Bahia, em 1646, a de São Luís, em 1702 e as do Rio e São Paulo - ${ }^{8}$ tinham tríplice função:

a) administrativa, configuradas no "carrego de todo o regimento da terra" e nas "avenças por jornais e empreitadas";

b) legislativas, pela fixação das posturas municipais e taxação de coletas e de fintas;

c) judiciais, ao despacharem os Vereadores como juízes ordinários, "sem apelação, os feitos das injúrias verbais e dos furtos pequenos". 9

No Império, o Intendente - nome dado ao Prefeito - era eleito pelos Vereadores, geralmente, ocupando a Presidência o mais votado no pleito direto, quando este substituiu as eleições indiretas, por cinco "homens bons", adotadas na Colônia.

Se, durante a I República, a Câmara Municipal pôde exercer funções executivas, por seu Presidente, na II República os Prefeitos foram nomeados pelos Interventores Federais e, ressurgindo as Câmaras Municipais, sob o regime da Constituição de 1934, passaram a ser simultaneamente eleitos Prefeitos e Vereadores, retornando-se, em 1937, ao sistema da II República.

Sob o regime da Constituição de 1946, as Cartas estaduais adjudicaram às Assembléias Legislativas atribuição para votar uma Lei Orgânica Municipal, procedimento que tem apoio no art. 200 da Constituição de 1967, com a redação que the foi dada pela Emenda Constitucional n. ${ }^{\circ}$ 1, de 1969.

6. Ora, como os Territórios Federais não têm autonomia, nem Constituinte própria, a Lei Orgânica Municipal será uma lei federal, regulamentando, no particular, a matéria constitucional. A vigente é o Decreto-lei $n .{ }^{\circ} 411$, de 8 de janeiro de 1969 , cujo Título II se dedica expressamente à matéria, declarando, no art. 49:

"Os Municípios dos Territórios têm todos os direitos e prerrogativas assegurados, na Constituição e nas Leis Federais, aos Municípios dos Estados". 
O Capítulo II desse Título disciplina a organização e funcionamento da Câmara Municipal, "órgão deliberativo do Município", versando a elegibilidade e casos de afastamento dos Vereadores, a competência da Câmara, os períodos legislativos e outras disposições regimentais, enquanto o art. 62 manda aplicar aos Vereadores Municipais dos Territórios o Decretolei $n .^{\circ} 201$, de 27 de fevereiro de 1967, quanto aos crimes de responsabilidade.

Advirta-se, neste passo, no atinente às Câmaras Municipais, que nenhum dispositivo do Decreto-lei $n .^{\circ} 411 / 69$ foi revogado pela Emenda Constitucional $n .^{\circ} 1$, aquela de janeiro e esta de outubro do mesmo ano.

7. As principais questões suscitadas em torno do assunto são as seguintes:

a) são remunerados os Vereadores das Capitais dos Territórios Federais?

b) o suplente pode substituir o Vereador, quando e por quanto tempo?

c) o Vereador pode reassumir o cargo antes de terminada a licença?

d) não assumindo o primeiro, pode ser convocado o segundo suplente?

A primeira vista, as perguntas "b" e "c" estão respondidas pelo art. 53 e seus $\S \S 3 .^{\circ}$ e $4 .^{\circ}$ do Decreto-lei $n .^{\circ} 411 / 69$, verbis:

“§3. Nos casos previstos neste artigo, nos de licença por mais de quatro meses ou nos de vaga, será convocado o suplente e, na falta deste, o fato será comunicado ao Juiz Federal.

"§ $4 .^{\circ} \mathrm{O}$ Vereador licenciado nos termos deste artigo não poderá reassumir o mandato antes do término da licença".

A quarta pergunta é respondida pelo art. $8 .^{\circ}$, II do Decretolei $n .{ }^{\circ} 201 / 67$, verbis: 
"Art. 8. - Extingue-se o mandato de Vereador e assim será declarado pelo Presidente da Câmara, quando:

II - deixar de tomar posse, sem motivo justo aceito pela Câmara, dentro do prazo estabelecido em lei".

Finalmente, a primeira indagação (" $\mathrm{a}$ ") encontra resposta no $\S 2 .^{\circ}$ do art. 15 da Constituição, verbis:

"§ 2. Somente farão jus à remuneração os Vereadores das Capitais e dos Municípios de população superior a duzentos mil habitantes, dentro dos limites e critérios fixados em lei complementar".

8. Releva notar, no entanto, a existência de um problema: a fixação do "quantum" da remuneração. Vigora, ainda, com modificação apenas quanto ao número de habitantes, a Lei Complementar $n .^{\circ} 2 / 67$ (desde que outra não foi votada pelo Congresso Nacional), onde se declara que essa remuneração será estabelecida por deliberação da Câmara Municipal, com as limitações previstas no artigo $3 .^{\circ}$ Ora, este artigo fala no critério da proporcionalidade em relação aos Deputados Estaduais, inexistentes nos Territórios.

Se a citada Lei Complementar é omissa - no caso do teto dos vencimentos dos Vereadores dos Territórios - mas a Constituição vigente garante sua remuneração, a resposta só pode ser encontrada, inicialmente, no art. $6 .^{\circ}$ da Lei Complementar $n .^{\circ} 2 / 69$, verbis:

"Art. 6. A despesa com a remuneração dos Vereadores não poderá ultrapassar, anualmente, a $3 \%$ da arrecadação orçamentária do respectivo Município no exercício anterior".

9. Já houve, também, interpretação contestatória quanto à convocação dos suplentes de Vereador nos Municípios dos Territórios Federais. Entendem alguns juristas que, por via do art. 200, cabe, mutatis mutandis, a aplicação do art. 36 da Constituição vigente às Câmaras Municipais, sem exceção, "no 
sentido de que a convocação de Vereador ocorre, apenas e tãosomente, no caso de vaga em virtude de morte, renúncia ao mandato ou investidura em funçäo correspondente à de Secre. tário de Estado, só devendo as Câmaras Municipais conceder licença a Vereador por necessidade comprovada de saúde". 10

Tal assertiva se funda nos seguintes argumentos:

"De fato, se se entendesse que o comando constitucional, inserto no art. 200 , caput, só autorizasse a incorporação ao Direito Constitucional legislado dos Estados das normas da Constituição Federal que, expressa ou nominalmente, se referissem aos Estadosmembros e aos Municípios, com seus correspondentes órgãos, representantes e instituições, importaria a esdrúxula tese na absoluta desnecessidade do preceito constitucional em exame, pois que a incidência já se achava expressa no texto, sem necessidade de adaptações. Seria um total e desenganado esvaziamento do texto constitucional".

Em parecer emitido na Consultoria do Interior 11 discordamos dessa conclusão. Àquela altura, os Estados haviam incorporado às suas Constituições os preceitos pertinentes da Emenda $n .^{\circ} 1 / 69$, por meio de Leis Orgânicas dos Municípios; mas, quanto aos Vereadores dos Territórios, integra restava a disciplina do Decreto-lei n. ${ }^{\circ} 411 / 69$.

Sustentamos, então:

"Data venia, trata-se de arrojada e descabida aplicação do texto constitucional. Senão, vejamos o que diz o texto da Emenda Constitucional n. ${ }^{\circ} 1 / 69$ :

"Art. 200. As disposições constantes nesta Constituição ficam incorporadas, no que couber, ao direito constitucional legislado nos Estados".

Mas não há esse cabimento, entendido por aquela interpretação, ao pretender tomar isoladamente o art. $36, \S 1 .^{\circ}$, da Constituição, que não se refere a Vereadores, mas se insere no Capítulo VI, "Do Poder Legislativo", qúe, na forma do art. 27. "é exercido pelo Congresso Nacional", que se compõe da Câmara dos Deputados e do Senado Federal. 
Poder é expressão da soberania que, na Federação, se exerce pela União, não pelos Estados e Municípios, detentores de autonomia. Apenas por extensão de uso, admite-se a denominação, dada aos órgãos legislativo e executivo estaduais, de "Poder". Assim, a letra "a" do $\S 10^{\circ}$ do art. 25 da Constituição fala em "Poder Executivo Federal", dando ensejo a que se considere possível a denominação "Poder Executivo Estadual". Mas não fala, uma vez sequer, em "Poder Legislativo Federal".

Não há discutir que o art. 200 pretendeu adotassem as Constituições estaduais aquelas alterações que a Emenda Constitucional $n .{ }^{\circ} 1 / 69$ trouxe ao funcionamento do legislativo federal, como, de resto, nem precisaria declará-lo, se manteve o sistema federativo. Mas daí não se infere pretendesse o legislador constituinte reconhecer a existência de "Poder Legislativo" nos Municípios, cuja Lei Orgânica é ditada pelas Assembléias Legislativas estaduais.

O Capítulo III da Constituição Federal vigente é que trata "Dos Estados e Municípios", a quem manda respeitar, em suas leis, "a forma de investidura nos cargos eletivos" por ela estabelecida (art. 13, item III).

0 art. 15 , referente à autonomia municipal, chega a disciplinar a remuneração dos vereadores - nos termos de Lei Complementar - enquanto o art. 16 atribui às Câmaras Municipais o controle externo da fiscalização financeira e orçamentária do Município. A restante disciplina da vereança municipal, nos Territórios, se encontra nos Decretos-leis $n .^{\circ} 411$, de 8 de janeiro de 1969 , e no de $n .^{\circ} 201$, de 27 de fevereiro de 1967 , que não podem ser contrariados por quaisquer leis municipais, respeitada a hierarquia legal do sistema federativo.

Teria a Constituição revogado aqueles decretos? Não. Disciplinando um a vereança em todo o País, outro o seu exercício nos Territórios Federais, só poderia sofrer alterações pelos artigos 13,15 e 16 da Emenda Constitucional - ou por legislação federal subseqüente de hierarquia constitucional - versando precisamente a matéria municipal. Nunca pela interpretação extensiva de incisos constitucionais referentes ao Poder Legislativo".

Tais os fundamentos que apresentamos naquele parecer datado de 11 de janeiro de 1971. 
10. Pouco depois, o Supremo Tribunal Federal, por acórdão de 4 de maio de 1972, acolhia, em sessão plenária e por unanimidade, a nossa tese.

A Consultoria Jurídica do Ministério da Justiça, aceitando tese adversa à nossa, sugerira ao respectivo Ministro representar ao Procurador-Geral da República, alegando a inconstitucionalidade parcial do art. 23, caput, do Decreto-lei n. 9 , de 31 de dezembro de 1969, do Estado de São Paulo, dispondo sobre a organização municipal, verbis:

"Art. 23. No caso de vaga ou de licença de Vereador, o Presidente convocará imediatamente o suplente".

Sustentava-se, na representação, que esse artigo contrariava a regra básica do art. $36, \S 1$. , da Constituição, limitativo da convocação do parlamentar às hipóteses de morte, renúncia ou investidura na função de Ministro de Estado.

Muito cauteloso, advertia o Procurador-Geral da República, explicando sua promoção:

"Fizemo-la porque, como nos chegou ao conhecimento, diferentes órgãos oficiais de assistência e orientação dos Municípios opinaram diferentemente sobre a legitimidade constitucional da convocação, deixando em estado de perplexidade as comunas interessadas".

Parece-nos interessante reproduzir alguns trechos do voto vitorioso do Ministro Bilac Pinto:

"A Emenda Constitucional n. 1, ao eliminar a convocação do suplente de deputado ou senador, em caso de licença do titular, teve em vista o prestígio e a boa reputação das duas Casas do Congresso Nacional, repetidamente comprometidas por práticas abusivas e fraudulentas em matéria de licenciamento de parlamentares, operação a que se vinculava, como objetivo principal, o recebimento de ajuda de custo por parte do suplente convocado. Em face da violação sistemática das normas regimentais que regulavam criteriosamente os casos de licença e de pagamento de ajuda de custo, a Constituição de 69 adotou solução radical: 
para eliminar as possibilidades daqueles deploráveis desvios, suprimiu a convocação dos suplentes em casos de licença dos parlamentares".

Depois de sustentar a aplicação das normas às Assembléias Legislativas e lembrar a gratuidade, como regra, do mandato de Vereador, acentua o Ministro Bilac Pinto:

"No que diz respeito a tais Vereadores, a norma permissiva ou proibitiva da convocação dos suplentes, em caso de licença dos titulares, será estabelecida na lei complementar, dada a relação entre o chamamento ao exercício e a respectiva remuneração. A Lei Complementar $n .^{\circ} 2$, de 29 de novembro de 1967 , que regula a remuneração dos vereadores prevista no art. 15 , $\S 2 .^{\circ}$, da Constituição, não incluiu qualquer norma proibitiva da convocação do suplente em caso de licença do membro da Câmara Municipal".

Concluindo o seu voto, lembrava:

"Devo, aliás, assinalar que o Prof. Xavier de Albuquerque, ilustre Procurador-Geral da República, que formulara a representação, convenceu-se de que o texto impugnado não apresenta vício manifesto de inconstitucionalidade, como assinalou em seu parecer".

Vale, igualmente, a pena, citar alguns trechos do voto do Ministro Thompson Flores, ao declarar:

"Como o eminente Relator, rejeito a inconstitucionalidade argüida, e, conseqüentemente, dou, também, pela improcedência da representação.

1. Para que ocorresse a inconstitucionalidade era mister que preexistisse disposição expressa ou implícita de aplicação aos vereadores para o efeito de convocação de seus suplentes, da regra que se contém no art. $36, \S 1 .^{\circ}$, da Carta Maior. Expressa, inexiste. Maior que seja o rigor atribuído aos arts. 10, VII e 13 e seus incisos e parágrafos, este pelo seu caput, em conjugação com os arts. $15, \S \S 2 .^{\circ}$ e $3 .^{\circ}, 19, \S 2 .^{\circ}$ e 64 , nada ocorre para justificar a aplicação daquela regra.

Implicitamente, não percebo, ademais. 
Antes, do parágrafo único do art. 14 , em conjugação com o § $1 .^{\circ}$ do art. 13 , tenho que poderia o Estado legislar a respeito, como o têm feito as Unidades da Federação em forma de L.O.M., salvo o Rio Grande Sul, o qual, segundo sua tradição, adota o princípio das Cartas-Próprias, ou seja, a faculdade de os Municípios elaborarem sua lei fundamental".

11. Para não alongar este trabalho, vejamos o que fizeram, no particular, os legisladores estaduais no Rio de Janeiro, Minas Gerais e São Paulo.

Em Minas, a Emenda Constitucional $n \cdot 1$, alterando a Constituição de 13 de maio de 1967, em obediência ao art. 200 da Lei Maior, não Ihe transcreveu 0 art. 36 , mas, no art. 169 , declara-se, verbis:

"Art. 169. Nos casos de vaga ou afastamento do Vereador, disciplinado na Lei Complementar de Organição Municipal, será convocado o respectivo suplente".

Já a Constituição de São Paulo (Emenda Constitucional n. 2 , de 30 de outubro de 1969) diz, no preâmbulo:

"Considerando que o novo texto constitucional, em seu art. 200, determina que as disposições nele contidas ficam incorporadas, no que couber, ao Direito Constitucional legislado dos Estados..." verbis:

E, no art. 12, tratando do Poder Legislativo Estadual dispõe,

“Art. 12. Dar-se-á a convocação de suplente apenas no caso de morte, renúncia ou investidura no cargo de Secretário de Estado".

Mas, na sua Lei Orgânica dos Municípios, permite, como vimos, a convocação do suplente em qualquer caso.

Igual solução é a dos legisladores fluminenses.

12. Não há, na doutrina nem no direito positivo, como equiparar Vereadores a Deputados, nem, muito menos, como concluirse pela existência de um "Poder Legislativo" municipal, apenas porque os Municípios votam suas leis ordinárias, ou porque o Poder Constituinte Originário transfira aos - Estados-membros uma parte dessa potestas. 
Assim doutrina MANUEL GONÇALVES FERREIRA FILHO: 12

"Chama-se Poder Constituinte decorrente aquele que, decorrente do originário, não se destina a rever sua obra, mas a institucionalizar coletividades, com caráter de Estado, que a Constituição preveja. É ele, pois, o Poder Constituinte dos Estados de uma Federação. Como Poder Constituinte instituído, o poder decorrente é subordinado, secundário e condicionado. Só pode agir validamente no âmbito fixado pelo originário".

Mas é este poder supérstite quem vai - necessária e exclusivamente - imprimir ordenamento à organização municipal, naquilo que não discrepe à Constituição Federal. Só há aplicação direta e imediata das normas constitucionais federais à legislação municipal quando assim claramente o preceitue a Lei Maior.

As Câmaras Municipais são simples órgãos deliberativos autônomos, não poderes. Esse o tratamento que lhes dão as vigentes Constituições e Leis Orgânicas Municipais de São Paulo, Minas Gerais, Rio de Janeiro e Paraíba, dentre outras. A de São Paulo (arts. 109 a 119) fala de órgãos do governo municipal, o Prefeito com funções executivas, a Câmara Municipal com funções legislativas. A de Minas Gerais declara (art. 152) a função deliberativa da Câmara Municipal. Também a Constituição fluminense (art. 21) chama a Câmara Municipal de órgão deliberativo, não falando em poderes municipais.

Eis o que dizem a doutrina e a jurisprudência, segundo HELY LOPES MEIRELLES: 13

"A Câmara de Vereadores é órgão legislativo do Município. Não é poder Legislativo no sentido constitucional dessa expressão, visto que no regime federativo, como o nosso, os Poderes do Estado são privativos da União e dos Estados-membros que a compõem. Fiel à nossa organização política, o Supremo Tribunal já proclamou que "as Câmaras Municipais são corpos legislativos e representativos que legislam, mas nem por isso são Câmaras do Poder Legislativo que, em cada. Estado, é um só, representado por sua Assembléia Legislativa". 
"Não vemos onde se possa engastar, na Constituição Federal, os decantados "Poderes do Município", nem lobrigamos os princípios políticos ou jurídicos que autorizem a existência dos "Poderes" Municipais".

"Por mais de uma vez tenho tido a oportunidade de verificar como pode ser levado a graves equívocos o legislador ou o intérprete da Constituição e das leis quando dominados pelo propósito de estender aos $\mathrm{Mu}$ nicípios e aos Estados princípios e normas válidos no ordenamento jurídico da União. O apego a soluções uniformes no escalonamento da estrutura federal, como se órgãos e funções públicas tivessem de necessariamente ordenar-se por um "princípio de simetria", tendo como padrão ou modelo o aplicável à esfera federal, pode ser fonte de ilações que não se ajustam às peculiaridades das províncias e das comunas".

13. De qualquer modo, parece-nos descabida a aplicação, por via do caput do art. 200, do art. $36, \S 1 .^{\circ}$ da Emenda n. $1 / 69$ aos Municípios dos Territórios Federais, onde não há "direito constitucional legislado dos Estados".

Além do que, o referido parágrafo, visando a policiar os gastos do Legislativo, indica uma coibição aos excessos financeiros das Casas Legislativas, conforme reconhece o já citado acórdão do Supremo Tribunal Federal. Como aplicar-se semelhante intenção ao mandato gratuito
de todos os vereadores dos Territórios, com exceção dos que exercem mandato nas Câmaras das Capitais?

Por que a interpretação anãlógica?

Analogia implica em situações equivalentes. No entanto, entre o Vereador e o Parlamentar há mais diferenças do que semelhanças, como se observa no seguinte quadro comparativo:

\section{Vereador}

Mandato geralmente gratuito Não tem imunidades Não é membro de Poder Sua Câmara recebe ordenamento de uma Lei Orgânica externa

\section{Parlamentar}

Mandato sempre oneroso Goza de imunidades É membro de Poder Sua Câmara só se ordena pela Constituição e resoluções "interna corporis" 
Quatro diferenças sobre duas semelhanças: ambos exercem mandato eletivo e função legislativa.

Seria possível considerar figuras análogas um trapézio e um hexágono, por que houvesse a superposição de dois lados?

Além disso, a disciplina pertinente aos Vereadores dos Municípios dos Territórios Federais só se estatui em leis federais ou municipais, enquanto a Emenda $n .^{\circ} 1 / 69$ não revogou nenhum artigo do Decreto-lei n. ${ }^{\circ} 411 / 69$, no que tange às Câmaras Municipais dos Territórios, disciplina que só se alterará por via de legislação federal. Assim, continuam eficazes as normas contidas nos parágrafos $2 .^{\circ}, 3 .^{\circ}$ e $4 .^{\circ}$ do art. 52 da Lei Orgânica dos Territórios:

a) no que tange à manutenção do mandato do Vereador nomeado Secretário do Governo ou Prefeito Municipal;

b) quanto à convocação de suplentes;

c) a respeito da reassunção do mandato só após transcorrido o prazo da licença.

Não há, na Emenda Constitucional n. 1/69, o menor vislumbre de referência à interrupção da licença parlamentar (admitida, ad argumentandum, a improcedente analogia), nem quanto ao exercício, pelo Vereador, das funções de Prefeito.

Demonstrado, à saciedade, que Vereador não é Parlamentar nem membro de Poder Legislativo, mas simples legislador municipal, inaceitável a colidência entre o art. $36, \S 1 .{ }^{\circ}$, da Constituição vigente e o $\S 3 .^{\circ}$ do art. 52 do Decreto-lei n. $.^{\circ} 411 / 69$ (Lei Orgânica dos Territórios), em pleno vigor.

Em abono à nossa tese, diz o jurista ANTONNIO TITO DA COSTA: ${ }^{14}$

"Duas questões têm sido freqüentemente postas em relevo, no tocante à convocação de suplente de Vereador: uma consistente em saber se ela se fará em qualquer hipótese, além dos casos de morte e renúncia do titular da cadeira; outra referente ao suplente a ser convocado: se do partido pelo qual o titular foi eleito (e o suplente também) ou se o da agremiação à qual esteja, no momento, pertencendo o titu- 
lar. Quanto à primeira questão, não temos dúvida em concluir que a convocação se fará em qualquer hipótese: licença, afastamento, renúncia, morte ou outro qualquer. O preceito do art. $36, \S 1 .{ }^{\circ}$, da Constituição Federal, não se aplica a nosso ver às Câmaras Municipais"... "Segundo entendemos, tal dispositivo não pode alcançar as Câmaras Municipais, porque endereçado especialmente aos membros do Congresso $\mathrm{Na}$ cional: Deputados e Senadores. Quando a Constituição pretende estender regras aos Estados e Municípios, ela o faz especificamente, como acontece, por exemplo, no capítulo dos funcionários públicos (art. 108). No Estado de São Paulo, a Lei Orgânica dos Municípios (Decreto-lei Complementar n. 9, de 31 de dezembro de 1969) tem regras expressas sobre a convocação de suplentes, nos casos de vaga ou licença de Vereador titular (arts. 21 a 23). Os casos de vaga seriam aqueles referidos na Constituição (renúncia ou morte), além da perda do mandato, por extinção ou cassação; os casos de licença são os previstos na lei orgânica".

“. . a convocação do suplente deve ser feita tanto no caso de vaga da cadeira do titular como no de licença deste".

14. O debate em torno da remuneração dos Vereadores temse alongado, tanto mais quanto, transcorridos quase quatro anos, não foi elaborada qualquer Lei Complementar destinada a fixar critérios e limites para esses subsídios, talvez por haver disciplina posterior à Constituição de 1967, cujo art. $16, \S 20^{\circ}$, é repetido no art. $15, \S 2 .^{\circ}$, da Emenda Constitucional n. $1 / 69$, com uma só diferença: exige-se, agora, população municipal de
duzentos mil habitantes, para que seja estipendiado o Vereador.

Acontece que a Lei Complementar n. 2/67 atendeu ao pressuposto constitucional e continua em vigor, até que nova Lei Complementar atenda à promessa dos citados artigo e parágrafo da Constituição vigente, esclarecendo os componentes da remuneração, condições de recebimento, duração de vigência (art. $2^{\circ}$ ) como no que tange à proporcionalidade dos quantitativos (arts. $3 .^{\circ}, 4 .^{\circ}$ e $5 .^{\circ}$ ).

A propósito, salienta LUIS RAFAEL MAYER, Consultor Jurídico do Ministério do Interior: ${ }^{15}$ 
“É irrecusável a validade do princípio de que não são afetados em sua vigência, em face da norma constitucional superveniente, os textos legais que estejam conforme ao novo preceito, hierarquicamente superior, ou, melhor, que não sejam por ele contrariados ou com ele não se mostrem incompatíveis. Regem, no caso, as normas constitucionais do direito intertemporal, no sentido que Pontes de Miranda chamou "princípio da continuidade da Legislação" (Comentários à Constituição de 1967, VI, p. 363). Em princípio, portanto, a Lei Complementar $n .^{\circ} 2 / 67$, que regulamentou o $\S 2 .^{\circ}$ do art. 16 da Constituição de 1967, encontra-se em pleno vigor no que não tenha sido contrariada pelas emendas constitucionais posteriores à sua edição".

Depois de assinalar o caráter de emenda do novo texto constitucional, semelhante ao da Lei Complementar, ambas nascidas no mesmo regime constitucional, "que ainda perdura", somando-se uma à outra, salienta o lúcido parecerista que "o dispositivo por ela regulamentado se alterou em parte delimitada e precisa do conteúdo, sem afetação do conjunto da norma, no seu sentido, finalidade e alcance. Nele apenas um parâmetro se modificou, sem prejuízo do todo, no quanto restou incólume".

Não houve total revogação, mas, quanto ao parâmetro populacional (de cem mil para duzentos mil habitantes), uma derrogação.

Prosseguindo, assinala aquele jurista que, se não podem ter remuneração só Vereadores de Municípios de população inferior a duzentos mil habitantes, podem-no os das capitais, "ainda que as populações respectivas sejam inferiores àqueles montantes, e quaisquer que sejam esses montantes".

"Nem a norma constitucional nem a norma complementar - acrescenta MAYER - ao se referirem a "capitais", opõem ao termo qualquer outro restritivo. Se a referência é genérica e se tanto nos Estados. como nos Territórios, há um Município que é Capital, sede de Governo, a norma constitucional e a complementar abrangem, no conceito "capitais", as capitais dos Estados e Territórios, pois as Capitais dos Territórios, tanto quanto as dos Estados, têm Vereadores Municipais". 
15. Surge, porém, outro problema, no que tange ao "quantum" da remuneração atribuível aos Vereadores das Capitais dos Territórios, já aqui por uma lacuna da Lei Complementar n. $2 / 67$, que, ao estabelecer, como paradigma à remuneração dos edis, os subsídios dos Deputados Estaduais, esqueceu a sua inexistência nos Territórios Federais.

Eis o dilema decorrente:

a) não havendo paradigma, não se pode quantificar a remuneração, impossibilitado o pagamento;

b) não se pagando, contraria-se o dispositivo constitucional que excepcionou da gratuidade o exercício do mandato pelos Vereadores das Capitais.

Entretanto, impossivel admitir o paradoxo, tanto mais quanto o raciocínio lógico deve ser outro: se o Vereador é pago, há que se descobrir o paradigma aparentemente esquecido pela Lei Complementar.

Vale repetir a constatação do parecer que vimos citando:

"Trata-se, portanto, de uma omissão involuntária da Lei. Mas omissão, veja-se bem, que recai exatamente sobre o paradigma da remuneração dos Vereadores dos Territórios, não sobre o direito à remuneração, que não é excluído, em nenhum passo, mas deflui explicitamente do texto, quando verificamos as condições dele geradoras".

Logo a seguir, o parecer indica um paradigma:

porção . a remuneração do Vereador guarda certa proos subsídios os subsídios do Deputado estadual; mas porção com os Deputado estadual guardam certa proVI, da E.C. os subsídios do Deputado federal (art. 13 , guarda Federal. Por proporção com os subsídios do Deputado re-se do pró operação matemática ou silogística, infea remunocio sistema, sem recorrer à analogia, que midaderação do Vereador pode ser fixada, na conforaos subsidindices postos na lei, em proporção certa 
Não queremos concluir este trabalho sem ferir outro aspecto da autonomia dos Municípios dos Territórios Federais: a obrigatoriedade da prestação de contas, pelos Prefeitos, às respectivas Câmaras.

$\mathrm{O}$ art. 55 e seu item IX e o art. 66, item VI do Decreto-lei n. $411 / 69$ declaram, "verbis":

"Art. 55. Compete privativamente à Câmara:

IX - julgar, no prazo de sessenta dias, após o recebimento, as contas do Prefeito".

“Art. 66. Compete ao Prefeito:

VI - apresentar à Câmara, até o dia 30 de março, as contas do exercício anterior, acompanhadas do relatório circunstanciado das atividades da administração municipal no mesmo período, sugerindo as providências que julgar necessárias".

Tais dispositivos não foram alterados pela Constituição vigente, conforme se verifica no art. 16 , verbis:

"Art. 16. A fiscalização financeira e orçamentária dos municípios será exercida mediante controle externo da Câmara Municipal e controle interno do Executivo Municipal, instituído por lei".

Apesar da clareza desses dispositivos, alguns Prefeitos de Municípios dos Territórios se recusaram à prestação de contas, alegando que o Decreto-lei n. 411/ 69 não tinha eficácia, por não ter sido cumprido o disposto no seu art. 84, verbis:

"Art. 84. O Poder Executivo regulamentará este Decreto-lei no prazo de 120 dias, sendo-lhe facultado dispor diferentemente, dentro dos limites legais, para cada Território, atendidas as peculiaridades locais".

Tal entendimento é descabido, pois, como assinala CLO. VIS BEVILÁQUA, "se apenas uma parte da lei depender de regulamento, somente se aplica à regra" da necessidade da regula- 
mentação a essa parte, plenamente eficaz a que dela não depende. ${ }^{16}$

Em parecer sobre a matéria, o Consultor Jurídico do $\mathrm{Mi}$ nistério do Interior assinala: ${ }^{17}$

"O Título II, do Decreto-lei n. $411 / 69$, referente à Organização Municipal, não deverá ser objeto de regulamentação, ora em razão de exaurir a matéria referente à estrutura municipal, no quanto possa ser objeto de uma lei orgânica, ora em razão do princípio da autonomia municipal, também reconhecida aos Municípios dos Territórios, que a estes reserva prover tudo quanto respeita ao seu peculiar interesse".

Tal tese foi aprovada por LUIZ OTÁVIO GALOTTI: ${ }^{18}$

"No tocante à Lei de Organização dos Territórios em cogitação, a prova de sua vigência, ainda que parcial, reside na própria realização das eleições ali previstas, a 30 de novembro de 1969".

"O dever de prestarem os Prefeitos contas de sua gestão e de se sujeitarem ao controle externo da Câmara se insere, aliás, na própria Constituição Federal, artigos $15, \S 3 .^{\circ}$ e 16 , pelo que seria de rigor a exigência, mesmo que a lei ordinária não a consignasse".

16. Eis como a autonomia dos Municípios situados em Territórios Federais não autônomos - simples circunscrições administrativas da União - nos conduz a sérias indagações jurídicas no campo do Direito Constitucional e, mais precisamente, na órbita do Direito Parlamentar, autorizando-nos as seguintes

\section{CONCLUSÕES :}

I - Continua plenamente em vigor a disciplina da vereança municipal estabelecida no Decreto-lei n. ${ }^{\circ} 411 / 69$;

II - Somente mediante lei federal se pode levar aos $\mathrm{Mu}$ nicípios dos Territórios a disciplina do art. 36 da Constituição
Federal;

III - Permanece remunerado o mandato dos Vereadores das Capitais dos Territórios, como continua em vigor a Lei Com. R. Serv. públ., Brasília, 108 (3) set./dez. 1973 
plementar $n . .^{\circ} 2 / 67$, menos quanto ao limite, agora de 200 mil habitantes, para a remuneração dos Vereadores dos demais Municípios;

IV - Não depende de analogia, mas de simples inferência lógica ou matemática, o critério para a remuneração dos Vereadores das Capitais dos Territórios;

V - As Leis Orgânicas dos Municípios (com exceção singular do Rio Grande do Sul) é que disciplinam os casos de preenchimento de vacância nas Câmaras Municipais;

VI - Não se pode, com base no direito positivo, na doutrina constitucional brasileira e na jurisprudência vitoriosa no Supremo Tribunal Federal, equiparar Vereador a Parlamentar;

VII - A Câmara de Vereadores é órgão deliberativo, mas não se configura em "Poder Legislativo".

VIII - Os Prefeitos dos Territórios Federais, embora nomeados pelos Governadores, são obrigados a prestar contas às respectivas Câmaras Municipais.

\section{BIBLIOGRAFIA}

1. OSCAR TENÓRIO, verbete "Autonomia Municipal", in "Repertório Enciclopédico do Direito Brasileiro", vol. 5, p. 190.

2. MAX FLEIUSS, "História Administrativa do Brasil", Melhoramentos, São Paulo, 2. ${ }^{a}$ ed., 1922, p. 1 a 45.

3. Apud Oscar Tenório, op. cit., p. 191.

4. PONTES DE MIRANDA, "Comentários à Constituição de 1967", Edit. Revista dos Tribunais, abril, 1969, tomo II. p. 339.

5. ROSAH RUSSOMANO, "O Princípio do Federalismo na Constituição Brasileira", 1965, p. 61.

6. M. G. FERREIRA FILHO, "Curso de Direito Constitucional", 1967, p. 78.

7. JOÃO JOSÉ DE QUEIROZ, "Câmara Municipal", in "Repertório Enciclopédico do Direito Brasileiro", vol. 6, p. 333.

8. Idem, p. 234, citando Araújo Castro e Cândido Mendes de Almeida, notas da p. $338, n .{ }^{\circ} \mathrm{s} 2$ e 4.

9. ORDENAÇÕES FILIPINAS, $10^{\circ}$ livro. Titulo LXVI e seguintes. 
10. Parecer do jurista CLENICIO DA SILVA DUARTE, apresentado ao Secretário-Geral do SERFHAU, no Proc. n. ${ }^{\circ} 14.323 / 70$, do Ministério do Interior.

11. QUEIRÓS CAMPOS, Parecer $n .^{\circ} 9 / 71$, na Consultoria Juridica do Ministério do Interior, no Processo n. ${ }^{\circ} 13.328 / 70$.

12. M. G. FERREIRA FILHO, "Curso de Direito Constitucional", Saraiva, 1967, pags. 27 e 28.

13. HELY LOPES MEIRELLES, "Direito Municipal Brasileiro", in "Revista dos Tribunais", 1964, pags. 574 a 585 do vol. II e 77 do vol. I.

14. ANTONNIO TITO DA COSTA, "Boletim Informativo do SENAM", julho, 1970, p. 28.

15. LUIZ RAFAEL MAYER, Parecer n. $0^{\circ} 84 / 71-$ C.J., nos processos $\ldots \ldots \ldots$. $n .{ }^{\circ} \mathrm{S} 12.588 / 70,11.733 / 70$ e 10.671 , do MINTER. 16. CLÓVIS BEVILÁQUA, "Comentários ao Código Civil Brasileiro, Vol. I,
pag. 91.

17. LUIZ RAFAEL MEYER, Parecer n. ${ }^{\circ} 42 / 70-$ C.J. do Ministério do Interior.

18. LUIZ OTÁVIO GALOTTI, Anexo II à Ata $n \cdot{ }^{\circ} 82$, de 5 de novembro de 1970, do Tribunal de Contas da União. 